\title{
Peningkatan Usaha Kreatif dan Pengelolaan Keuangan Berbasis Akuntansi Keluarga di Desa Pabelan Kabupaten Semarang dalam Rangka Peningkatan Ketahanan Ekonomi Keluarga
}

\author{
Indri Kartika*, Sri Dewi Wahyundaru, Sri Sulistyowati, Afri Aulia Rahman
}

Akuntansi, Fakultas Ekonomi, Universitas Islam Sultan Agung, Semarang, Indonesia

\author{
*Corresponding Author \\ Email: indri@unissula.ac.id \\ Jl. Raya Kaligawe Km. 4 PO Box. 1054, Semarang 50112, Indonesia, Telp: 024-6583584, Fax: 024-
} 6582455

$\begin{array}{lccc}\text { Received: } & \text { Revised: } & \text { Accepted: } & \text { Published: } \\ \text { 12 January 2021 } & \text { 26 May 2021 } & \text { 23 September 2021 } & \text { 24 November 2021 }\end{array}$

\begin{abstract}
Abstrak
Di masa pandemi saat ini banyak keluarga yang mengalami penurunan penghasilan karena menurunnya aktivitas di luar rumah, bahkan beberapa keluarga mengalami kesulitan keuangan karena menjadi korban PHK. Diperlukan usaha-usaha kreatif serta pengelolan keuangan yang cerdas agar ketahanan ekonomi keluarga bisa tetap terjaga. Kelompok ibuibu PKK di Desa Pabelan, Kecamatan Pabelan, Kabupaten Semarang memiliki latar belakang, tingkat sosial, pendidikan dan ekonomi yang berbeda-beda. Sebagian merupakan pekerja, pedagang, wirausaha kecil menengah, buruh industri dan pegawai harian lepas, namun kebanyakan masih memiliki waktu luang dapat diberdayakan dalam kegiatan pengembangan usaha kreatif. Kegiatan pengabdian masyarakat yang dilaksanakan oleh Team dari Fakultas Ekonomi Unissula yang terdiri dari Indri Kartika, Sri Sulistyowati, Sri Dewi Wahyundaru dan Afri Aulia Rahman dilakukan guna meningkatkan penghasilan dari usaha kreatif melalui pemasaran digital sederhana serta pengelolaan keuangan berbasis akuntansi keluarga. Peserta pelatihan meliputi ibu-ibu kelompok PKK di Desa Pabelan Kecamatan Pabelan Kabupaten Semarang. Metode pengabdian masyarakat dilaksanakan dengan penyuluhan, tanya jawab dan diskusi, dilanjutkan dengan praktik. Dari pelaksanaan pengabdian masyarakat dapat disimpulkan bahwa masyarakat tertarik untuk memulai usaha kreatif dan menerapkan pengelolaan keuangan berbasis akuntansi keluarga.
\end{abstract}

Kata kunci: usaha kreatif; e-commerce; pengelolaan keuangan; akuntansi keluarga

\begin{abstract}
During pandemic condition, many families have experienced income loss due to outdoor activity limitation. Some families even experience financial difficulties for losing job. Creative activities and smart financial management are needed so that the economic resilience of the family can be maintained. PKK women's group in Pabelan Village, Pabelan District. Semarang Regency has different backgrounds, social, educational and economic levels. Some are workers, traders, small and medium entrepreneurs actors, industrial laborers and casual daily employees. However, most of them still have free time to be empowered in creative business development activities. This community service activity was performed by members of Economic Faculty of Unissula which are: Indri Kartika, Sri Dewi Wahyundaru, Sri Sulistyowati and Afri Aluia Rahman. The purpose of this activity is to increase participant's business income during this pandemic situation through applying simple digital marketing and financial management based on family accounting in Pabelan
\end{abstract}


Village so that it can increase the income and welfare of the Pabelan villagers. Community service methods are carried out with counseling, discussion, followed by practice. From the implementation of community service, it can be concluded that the community is interested in starting creative businesses and implementing family accounting-based financial management.

Keywords: Creative activities; e-commerce; financial management; family accounting

\section{PENDAHULUAN}

Desa Pabelan merupakan salah satu desa yang ada di Kecamatan Pabelan Kabupaten

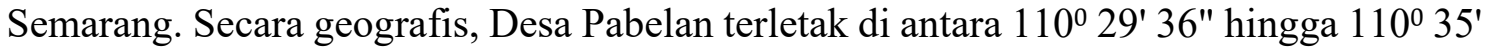
14" Bujur Timur dan $7^{0}$ 15' 24" hingga $7^{\prime}$ 20' 45" Lintang Selatan. Secara administrasi, Kecamatan Pabelan berbatasan langsung dengan Kecamatan Bringin di bagian utara, Kecamatan Bancak dan Suruh di bagian timur, Kecamatan Tengaran di bagian selatan dan Kabupaten Salatiga di bagian barat.Desa Pabelan dengan luas wilayah $2,7 \mathrm{~km}^{2}$ memiliki jumlah penduduk 3,439 dimana sejumlah 1.741 jiwa adalah laki - laki dan perempuan 1,698 jiwa. Banyaknya sarana perekonomian berupa warung/ toko/ kios sebesar 54, industri kecil sebanyak 5, dan industri rumah tangga sebanyak 4 (BPS, 2020).

Desa Pabelan memiliki kelompok ibu-ibu PKK dengan berbagai latar belakang, tingkat sosial dan ekonomi. Di antara mereka ada yang berperan sebagai ibu rumah tangga, namun sebagian merupakan pekerja baik itu dengan memiliki usaha kecil seperti toko kelontong, menjadi guru, pegawai maupun usaha mandiri lainnya. Sejak Pandemi masyarakat mengalami penurunan pendapatan. Penurunan pendapatan mengakibatkan penurunan daya beli masyarakat. Akibat turunnya daya beli masyarakat di masa pandemi seperti saat ini, tidak sedikit pengusaha termasuk usaha rumahan yang kesulitan menjalankan bisnisnya yang berakibat pada banyaknya usaha yang terpaksa harus dihentikan (Sugiri, 2020).

Beberapa pengamat menyatakan bahwa justru dengan keadaan pandemi yang ada seperti saat ini, semestinya bisa menjadi peluang yang harus dimanfaatkan oleh para pelaku usaha untuk memaksimalkan penggunaan e-commerce atau pemasaran digital. Ecommerce sebagai transaksi pembelian dan penjualan dengan pertukaran barang, jasa dan informasi kedua belah pihak melalui media internet. E-commerce dianggap sebagai solusi yang sangat tepat bagi para pelaku usaha untuk tetap bisa mempertahankan bisnisnya di masa seperti saat ini. Dengan e-commerce pelaku usaha tetap bisa memasarkan produknya tanpa harus bertemu secara langsung dengan konsumen (Wibisono \& Saputro, 2020).

Penggunaan strategi pemasaran digital merupakan suatu bentuk kemajuan teknologi informasi yang dapat memberikan banyak perubahan dalam dunia bisnis sebagaimana dapat menurunkan biaya, mempermudah proses promosi, sertakesempatan memperluas pangsa pasar baru tanpa harus mengeluarkan biasa yang besar (Laudon \& Traver, 2014). Banyaknya pengguna internet aktif saat ini mengindikasikan bahwa potensi penggunaan strategi pemasaran berbasis e-commerce cukup besar. Penggunaan strategi pemasaran digital berupa e-commerce membuat banyak pelaku usaha dapat dengan mudah memasuki pasar global yang memiliki potensi pasar yang luas dan bersifat realtime. Dengan sifatnya yang realtime menjadikan para pelaku usaha dengan secara mudah membangun kemitraan serta membangun hubungan baik dengan pelanggannya. 
Dengan menggunakan e-commerce dapat memperluas pangsa pasar serta menekan biaya yang sudah tidak efektif penggunaannya sehingga akan berdampak pada meningkatnya kinerja keuangan perusahaan. Media sosial semakin banyak digunakan oleh para ibu rumah tangga selain untuk menghubungkan teman dan relasi yang jauh juga dimanfaatkan sebagai media untuk mengembangkan bisnisnya (Vernia, 2017).

Dijelaskan dalam UU No.11 Tahun 2008 tepatnya pada pasal 1 ayat (2) mengenai informasi dan Transaksi Elektronik, e-commerce adalah perbuatan hukum yang dilakukan dengan menggunakan komputer, jaringan komputer, dan/atau media elektronik lainnya. Dalam transaksi e-commerce terdapat penggolongan yang lazim dilakukan oleh para pelaku bisnis berdasarkan sifat transaksinya. E-commerce dapat dibedakan tipenya sebagaimana berikut ini (Laudon \& Traver, 2014):

1) Business to Business (B2B) adalah suatu model bisnis e-commerce yang dimana para pelaku yang terlibat di dalam bisnis tersebut adalah antar perusahaan dengan perusahaan lainnya.

2) Business to Consumer (B2C) adalah suatu model bisnis e-commerce yang dimana para pelaku yang terlibat di dalam bisnis tersebut melibatkan antara pihak penjual dan pembeli secara langsung tanpa adanya perantara.

3) Consumer to Consumer (C2C) adalah suatu model bisnis e-commerce yang dimana para pelaku yang terlibat di dalam bisnis tersebut melibatkan antara perorangan atau individu yang menjadi penjual dengan pembeli yang berinteraksi secara langsung. Konsep e-commerce jenis inilah yang paling banyak diterapkan di dalam situs lelang.

4) Mobile e-commerce ( $\mathrm{m}$-commerce) adalah suatu model bisnis e-commerce yang mengacu pada penggunaan perangkat mobile untuk memungkinkan bertransaksi online dengan menggunakan sebuah jaringan.

5) Social e-commerce adalah suatu model bisnis e-commerce yang menggunakan jejaring media sosial. Sosial e-commerce sangat sering dihubungkan dengan jenis m-commerce, hal ini disebabkan banyaknya pengguna jariangan sosial yang mengakses menggunakan perangkat mobile.

6) Local e-commerce adalah suatu model bisnis e-commerce yang berfokus untuk melibatkan consume berdasarkan lokasi tempat tinggal saat ini. Pedagang local menggunakan berbagai teknik pemasaran online guna mengajak konsuman ke toko mereka.

Selain upaya pemasaran digital sederhana oleh pelaku usaha rumah tangga dikalangan, pengelolaan keuangan rumah tangga juga menjadi satu hal yang perlu dilakukan dalam upaya meningkatkan ketahanan ekonomi rumah tangga. Dalam setiap keluarga pengelolaan keuangan menjadi sesuatu yang sangat penting. Kegagalan keluarga dalam mengelola keuangan dapat mengakibatkan defisit yang berkepanjangan yang pada akhirnya dapat menyebabkan ketidakharmonisan sehingga ketahanan keluarga akan terancam. Hal ini sering dialami, tanpa disadari karena tata keuangan keluarga masih belum optimal karena masih kurangnya pengetahuan mengenai akuntansi dan manajemen keuangan keluarga.

Akuntansi adalah seni pencatatan, penggolongan, peringkasan transaksi, dan kejadian, yang bersifat keuangan dengan cara yang berdaya guna dan dalam bentuk satuan uang, dan penginterprestasian hasil proses tersebut (Suwardjono, 1999). Mayoritas 
masyarakat mempersepsikan akuntansi hanya digunakan di dalam bisnis, namun menurut Manurung \& Sinton penggunaan pencatatan akuntansi ini sangat baik dilakukan oleh keluarga dengan harapan keluarga memiliki informasi terkait besaran pengeluaran setiap kebutuhan rumah tangga sehingga pada akhirnya dapat dilaksanakan pengelolaan keuangan yang baik (Manurung \& Sinton, 2013).

Latar belakang masalah yang ditemui di lapangan sebelum pelaksanaan program pengabdian masyarakat, diketahui bahwa ibu-ibu PKK Desa Pabelan yang telah memiliki maupun masih dalam perencanaan untuk memiliki usaha kreatif belum masih bergantung pada sistem pemasaran konvensional dengan pengelolan keuangan yang belum memadai. Oleh karena itu masalah yang dirumuskan dalam kegiatan pengabdian masyarakat ini adalah: Bagaimana peningkatan pendapatan usaha rumah tangga dan pengelolaan keuangan yang baik sehingga dapat menciptakan ketahanan ekonomi keluarga?

Adapun tujuan yang ingin dicapai dari kegiatan pengabdian masyarakat ini adalah sebagai berikut:

1. Untuk memberikan penyuluhan dan pendampingan dalam mendukung usaha kreatif dengan potensi yang dimiliki oleh warga.

2. Untuk memberikan pemahaman pentingnya menerapkan akuntansi keluarga yang baik

3. Untuk meningkatkan ketahanan ekonomi rumah tangga melalui strategi pemasaran digital sederhana bagi usaha mikro skala rumah tangga serta pengelolaan keuangan rumah tangga yang lebih baik

Kegiatan pengabdian masyarakat ini diharapkan dapat memberikan manfaat sebagai berikut:

1. Peningkatan ide masyarakat khususnya ibu rumah tangga untuk menciptakan usaha kreatif yang dapat menghasilkan pendapatan serta peningkatan pendapatan usaha kreatif yang dimiliki.

2. Pemahamana masyarakat terhadap pentingnya akuntansi keluarga yang baik

3. Terciptanya silaturahmi yang baik antara perguruan tinggi dengan masyarakat sehingga perguruan tinggi dapat berkontribusi dalam pemberdayaan masyarakat

\section{METODE PELAKSANAAN}

\section{Pelaksana Pengabdian Masyarakat dan Profil Peserta}

Kegiatan pengabdian masyarakat di Desa Pabelan Kabupaten Semarang dilaksanakan oleh kelompok pengabdian masyarakat Fakultas Ekonomi Unissula yang terdiri dari:

1. Dr. Hj Indri Kartika, S.E., M.Si, Akt selaku ketua kelompok

2. Sri Dewi Wahyundaru, S.E., M.Si, Akt, CA selaku anggota kelompok

3. Sri Sulistyowati, S.E., M.Si selaku anggota kelompok

4. Afri Aulia Rahman selaku anggota kelompok.

\section{Sasaran Penyuluhan dan Profil Peserta}

Kegiatan pengabdian masyarakat ini di diperuntukkan bagi ibu rumah tangga baik yang memiliki usaha skala rumah tangga sebagai usaha sampingan maupun usaha utama. Bagi ibu rumah tangga yang belum memiliki usaha sampingan, kegiatan ini tetap memberikan manfaat untuk diikuti untuk membuka wawasan peluang menginisiasi usaha skala rumah tangga serta mempelajari pengelolaan keuangan dengan sistem akuntansi sederhana. 
Selain itu selama pelatihan juga akan diberikan ide untuk melaksanakan kegiatan usaha kreatif yang memungkinkan untuk dilakukan oleh ibu rumah tangga sebagai usaha sampingan dari rumah.

Adapun kegiatan penyuluhan diikuti oleh anggota kelompok PKK Desa Pabelan Kecamatan Pabelan Kabupaten Semarang. Berdasarkan tabel profil peserta pelatihan, diketahui bahwa sekitar $45 \%$ peserta pelatihan merupakan pelaku usaha mikro skala rumah tangga. Jenis usaha yang dilakukan bervariasi mulai dari memiliki toko kelontong, usaha toko pakaian, menjadi penjahit, menjadi guru senam, membuka jasa laundry, menjual makanan kecil, membuka warung makanan, hingga usaha menjual barang keperluan rumah tangga dengan sistem door to door. Profil peserta pelatihan tersaji dalam tabel berikut ini:

Tabel 1

Profil Peserta Program Pengabdian Masyarakat Tahun 2020 Desa Pabelan Kabupaten Semarang

\begin{tabular}{llccccc}
\hline & & \multicolumn{2}{c}{ Pendidikan } & \multicolumn{3}{c}{ Profesi } \\
\cline { 3 - 7 } No & Keterangan & $\begin{array}{l}\text { Sekolah } \\
\text { Menengah }\end{array}$ & $\begin{array}{l}\text { D3/Sarjana } \\
\text { Pascasarjana }\end{array}$ & Pegawai & $\begin{array}{l}\text { Ibu } \\
\text { Rumah } \\
\text { Tangga }\end{array}$ & Wiraswasta \\
\hline 1 & $\begin{array}{l}\text { Pendidikan } \\
\text { Profesi } \\
\text { JUMLAH }\end{array}$ & 9 & 21 & & 7 & 13 \\
\hline
\end{tabular}

\section{Pelaksanaan Pelatihan}

Kegiatan diawali dengan menyampaikan materi penyuluhan. Materi penyuluhan diawali dengan pentingnya ketahanan ekonomi dalam keluarga. Ketahanan ekonomi yang baik akan menjadi sumber utama kebahagiaan keluarga. Untuk menciptakan ketahanan ekonomi sumber pendapatan tidak hanya dibebankan kepada para suami, namun para ibu juga dapat berperan mendukung pendapatan keluarga. Pendapatan keluarga yang baik, belum tentu dapat dimanfaatkan secara optimal. Dengan akuntansi keluarga dapat dilakukan perencanaan, pengelolaan dan pencatatan keuangan keluarga, sehingga keuangan keluarga menjadi terjaga.

\section{Tanya Jawab}

Setelah kegiatan penyuluhan selesai diberikan kesempatan kepada para peserta untuk menanyakan hal-hal yang belum dipahami, masalah yang dihadapi dan diberikan solusi atas permasalahan tersebut.

\section{Praktik}

Praktik dilakukan mengenai bagaimana penerapan akuntansi sederhana dalam keluarga. Dengan mengidentifikasi sumber-sumber penghasilan keluarga kemudian dicatat. Dibuat perencanaan dalam satu bulan berdasarkan kebutuhan pengeluaran. Dibuatlah amplopamplop yang diisi dengan uang yang akan digunakan dalam satu bulan. Simulasi pembelanjaan secara disiplin dengan menggunakan uang yang ada di setiap amplop dan selanjutnya mencatat penggunaan uang dan membandingkan penggunaan uang dengan rencana yang telah dibuat sebelumnya. Selanjutnya melakukan evaluasi atas perbandingan rencana dengan realisasi. 


\section{Indonesian Journal of Community Services}

Volume 3, No. 2, November 2021

http://jurnal.unissula.ac.id/index.php/ijocs

DOI: http://dx.doi.org/10.30659/ijocs.3.2.135-144

\section{HASIL DAN PEMBAHASAN}

Kegiatan pengabdian masyarakat dilaksanakan pada tanggal 12 September, bertempat di mushola desa Pabelan, kecamatan Pabelan, Kabupaten Semarang. Acara dimulai pada pukul 9.00 WIB, dihadiri oleh 30 peserta dari kelompok PKK desa Pabelan.

Kegiatan diawali dengan penyampaian materi tentang kondisi ekonomi dalam situasi pandemi, peluang-peluang usaha di masa pandemi. Kemudian dilanjutkan dengan pemasaran berbasis digital sederhana. Di akhir sesi penyampaian materi tentang pengelolaan keuangan berbasis akuntansi keluarga.

Berdasarkan tanya jawab dan diskusi dengan peserta pendampingan dapat diketahui bahwa: Semua keluarga mengalami penurunan penghasilan akibat pandemi Covid-19. Penurunan penurunan daya beli masyarakat dan berkurangnya aktivitas di luar rumah menjadi penyebab utama omzet usaha juga mengalami penurunan. Untuk menjaga ketahanan ekonomi keluarga para ibu perlu membantu pasanganya agar kebutuhan keluarga dapat tercukupi. Potensi berupa keahlian ibu-ibu diantaranya membuat gorengan, rempeyek, makanan kering dan kerajinan tangan dapat dikembangkan menjadi sumber penghasilan yang menjanjikan. Terutama makanan kering dan kerajinan tangan dapat dipasarkan dengan jangkauan yang lebih luas melalui pemasaran digital. Ibu-ibu sangat antusias mencoba cara pemasaran baru melalui pemasaran digital karena sebetulnya ada cara-cara menjual produk maupun jasa yang cukup sederhana dan bisa dilakukan oleh peserta pelatihan.

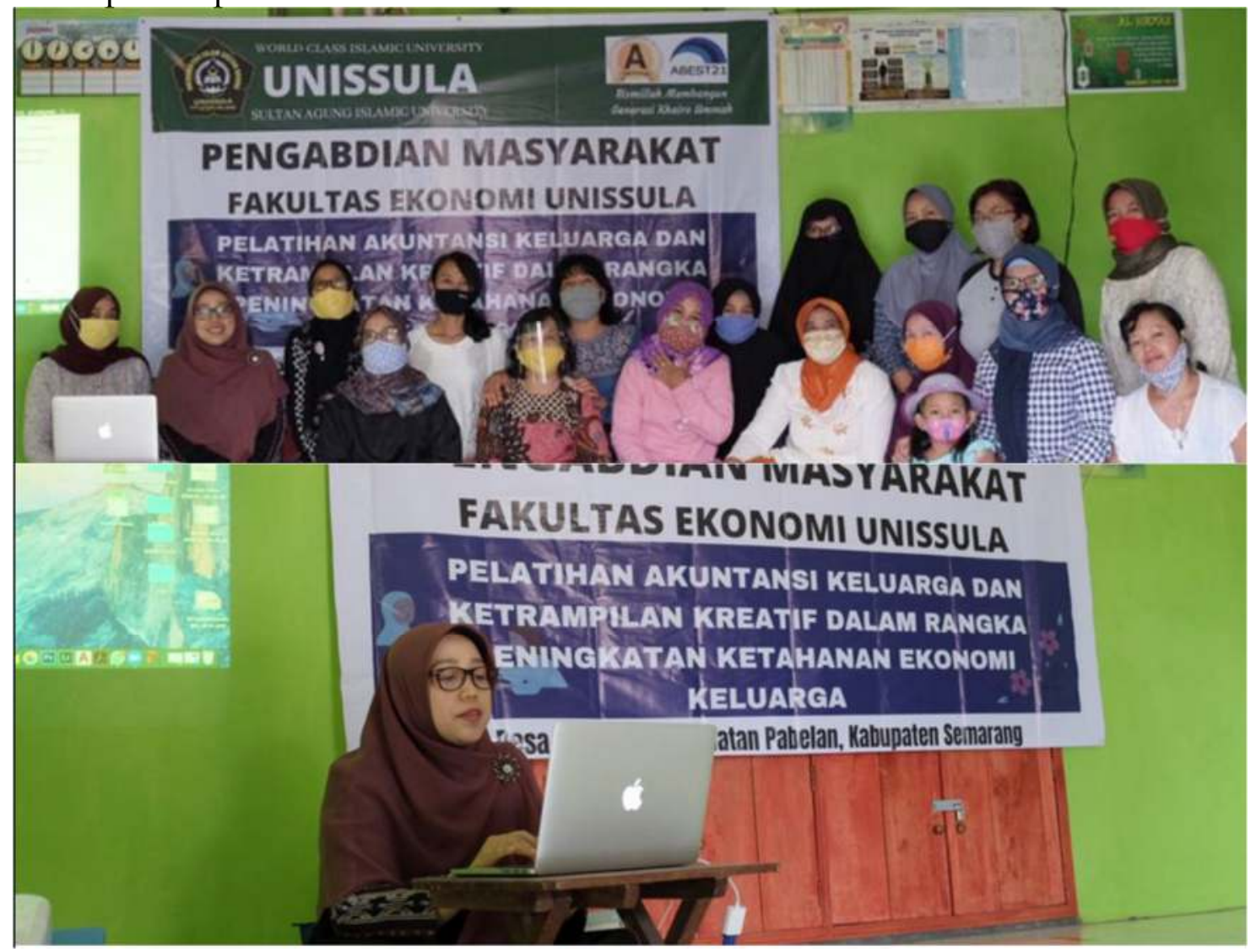

Gambar 1. Foto Pelaksanaan Kegiatan Pengabdian Masyarakat Sumber: Dokumen Pribadi 
Contoh penggunaan pemasaran digital yang paling sederhana dan bisa dilakukan oleh peserta pelatihan adalah pemasaran dengan melakukan promosi melalui fasilitas "story" di aplikasi mengirim pesan seperti WhatsApp, Telegram, maupun aplikasi pesan lainnya. Sebagaimana kita tahu, aplikasi pesan yang ada saat ini sudah dipergunakan secara luas dikalangan masyarakat termasuk dikalangan ibu-ibu disebabkan karena tidak berbayar dan mudah pengoperasiannya. Dengan memanfaatkan fasilitas story pada aplikasi pesan tersebut pengguna bisa berbagi aktivitas maupun berbagi informasi melalui menu status dimana status bisa berupa foto, video maupun teks. Hasil penelitian (Wibisono \& Saputro, 2020) membuktikan bahwa Penggunaan fitur-fitur yang dimiliki oleh WhatsApp terbilang sudah cukup untuk pemasaran secara pribadi dan intim antara penjual dan pembeli, penggunaan fitur story WhatsApp memang yang paling diminati dalam broadcast produk yang akan dijual. Promosi melalui aplikasi pesan juga bisa dilakukan dengan menawarkan produk atau jasa di group chat yang diikuti pengguna aplikasi. Ini merupakan salah satu bentuk promosi digital yang murah namun cukup efektif untuk usaha skala rumah tangga yang biasanya membidik konsumennya di lingkungan sekitar.

Penggunaan media sosial juga dipandang cukup efektif dalam melakukan pemasaran digital. Media sosial seperti Instagram, facebook maupun TikTok sangat populer dikalangan masyarakat dibuktikan dengan banyaknya jumlah pengguna yang memiliki akun media sosial tersebut. Saat ini media sosial juga telah menawarkan penggunanya untuk melaksanakan promosi dengan biaya yang cukup terjangkau. Ini akan sangat bagus dilakukan jika pelaku usaha ingin memperluas jangkauan pemasarannya. Hasil penelitian (Indika \& Jovita, 2017) membuktikan bahwa aplikasi media sosial Instagram yang menonjolkan sharing foto atau gambar terbukti punya korelasi kuat dalam mempengaruhi minta konsumen (Andes \& Sunaryanto, 2020). Peserta pelatihan kemudian diberikan contoh bagaimana memanfaatkan fasilitas promosi dengan menggunakan media sosial tersebut.

Strategi pemasaran digital yang juga bisa digunakan adalah dengan menggunakan aplikasi jual beli online seperti Shopee, Tokopedia, Buka Lapak, blibli dot com dan masih banyak lagi lainnya (Raharjo \& Prasetyo, 2018). Saat ini, penggunaan aplikasi jual beli online ini semakin populer dikalangan masyarakat sejak dikeluarkannya anjuran untuk melaksanakan social distancing. Dalam kesempatan pengabdian ini, diajarkan juga bagaimana penggunaan aplikasi tersebut sabagai salah satu strategi pemasaran digital.

Tanya jawab dan diskusi selanjutnya dapat diketahui bahwa para ibu mengalami kesulitan mengelola keuangan. Problem utama yang dihadapi adalah uang sudah habis sedangkan belanja-belanja penting belum dilakukan. Solusinya adalah dengan perapatan akuntansi keluarga. Berikut ini adalah tahapan dalam penerapan akuntansi keluarga:

Pertama, mengidentifikasi sumber-seumber penghasilan yang terdiri dari: penghasilan utama suami, penghasilan utama isteri dan penghasilan sampingan. Selanjutnya menyusun daftar kebutuhan selama satu bulan, yang terdiri dari: kebutuhan primer, meliputi Pangan, sandang, papan, kesehatan, pendidikan, iuran kampung, zakat (shodaqoh),dll . Kebutuhan sekunder, yang meliputi Wisata, Alat Komunikasi. Kebutuhan tersier, yang meliputi: Arisan tidak wajib, ganti HP. Rumus alokasi dana adalah: Penerimaan $=$ Pengeluaran $+10 \%$.

Kedua, membuat daftar rencana penerimaan dan pengaluaran, misalnya sebagai berikut: 


\section{Indonesian Journal of Community Services}

Volume 3, No. 2, November 2021

http://jurnal.unissula.ac.id/index.php/ijocs

DOI: http://dx.doi.org/10.30659/ijocs.3.2.135-144

Tabel 2

Rencana Penerimaan dan pengeluaran Bulan Juli 2020

\begin{tabular}{|c|c|c|c|c|c|}
\hline \multicolumn{3}{|c|}{ Penerimaan } & \multicolumn{3}{|c|}{ Pengeluaran } \\
\hline No & Jenis & Jumlah (Rp) & No & Jenis & Jumlah \\
\hline 1 & Pendapatan utama & $6.000 .000,00$ & 1 & Konsumsi & $3.000 .000,00$ \\
\hline 2 & Pendapatan sampingan & $1.000 .000,00$ & 2 & Cicilan rumah & $1.000 .000,00$ \\
\hline & & & 3 & Kesehatan \&kosmetik & $500.000,00$ \\
\hline & & & 4 & Pakaian & $200.000,00$ \\
\hline & & & 5 & Transportasi & $300.000,00$ \\
\hline & & & 6 & Pendidikan & $200.000,00$ \\
\hline & & & 7 & Zakat & $125.000,00$ \\
\hline & & & 9 & Iuran kampung & $200.000,00$ \\
\hline & Jumlah & $7.000 .000,00$ & & Jumlah & $6.025 .000,00$ \\
\hline & Saldo & $975.000,00$ & & & \\
\hline
\end{tabular}

Ketiga, memasukkan uang kedalam amplop-amplop sesuai dengan rencana pengeluaran. Dalam contoh terdapat 9 jenis pengeluaran dan saldo pengeluaran, maka disiapkan 10 amplop. Setiap amplop di bagian luarnya dituliskan jenis pengeluaran dan jumlah uang yang dianggarkan, termasuk saldo yang direncanakan. Setelah amplop selesai ditulisi kemudian diisi uang sebanyak jumlah yang tertera di luar amplop. Selanjutnya amplop berisi uang tersebut disimpan di tempat yang aman.

Keempat, membelanjakan uang secara disiplin sesuai dengan rencana

Hasil diskusi dengan peserta pendampingan adalah kesulitan untuk menggunakan uang sesuai dengan kebutuhan. Hal ini sering terjadi adalah kurangnya disiplin dalam membelanjakan uang. Kita sering menyebutnya dengan hidup sederhana, artinya adalah hidup sesuai dengan kebutuhan bukan sesuai dengan keinginan. Hidup sederhana berarti kutamampu mengelola pendapatan untuk memenuhi kebutuhan sehari-hari. Konsumsi tidak melampaui pendapatan, atau seharusnya pendapatan yang mengatur pola konsumsi. Hidup sederhana bukan berarti makan tidak bergizi, pakaian tidak pantas atau tidak terlibat dalam urusan kampung karena takut mengeluarkan. Tetapi hidup sederhana adalah hidup sesuai dengan kebutuhan yang kita miliki, hisup sehat, gizi terpenuhi, pakaian pantas, rumah bersih dan baghagia bertetangga. Hidup sederhana adalah hidup yang bermartabat.Disiplin dalam rencana pengeluaran adalah kunci hidup sederhana, untuk itulah setiap akan membelanjakan uang kita mengambil amplop yang sesuai, kemudian kita menyadari jumlah uang yang masih tersisa di dalam amplop harus mencukupi untuk 1 bulan.

Kelima, mencatat realisasi pendapatan dan pengeluaran

Setiap akhir bulan, kita perlu mencatat realisasi penerimaan dan pengeluaran, selanjutnya melakukan evaluasi perbandingan rencana dengan realisasi untuk mengetahui penyimpangannya dan menjadi catatan untuk pengeluaran bulan depan. Contoh perbandingan realisasi dengan rencana penerimaan dan pengeluaran adalah sebagai berikut: 
Tabel 3

Perbandingan Realisasi Rencana Penerimaan dan pengeluaran Bulan Juli 2020

\begin{tabular}{|c|c|c|c|c|c|c|c|}
\hline \multicolumn{4}{|c|}{ Penerimaan } & \multicolumn{4}{|c|}{ Pengeluaran } \\
\hline No & Jenis & Rencana & Realisasi & No & Jenis & Rencana & \\
\hline 1 & $\begin{array}{l}\text { Pendapatan } \\
\text { utama }\end{array}$ & $6.000 .000,00$ & $6.000 .000,00$ & 1 & Konsumsi & $3.000 .000,00$ & $3.000 .000,00$ \\
\hline \multirow[t]{11}{*}{2} & Pendapatan & $1.000 .000,00$ & $500.000,00$ & 2 & Cicilan rumah & $1.250 .000,00$ & $1.250 .000,00$ \\
\hline & & & & 3 & $\begin{array}{l}\text { Kesehatan } \\
\text { \&kosmetik }\end{array}$ & $300.000,00$ & $400.000,00$ \\
\hline & & & & 4 & Pakaian & $400.000,00$ & $100.000,00$ \\
\hline & & & & 5 & Transportasi & $300.000,00$ & $300.000,00$ \\
\hline & & & & 6 & Pendidikan & $200.000,00$ & $200.000,00$ \\
\hline & & & & 7 & Zakat & $100.000,00$ & $100.000,00$ \\
\hline & & & & 9 & Iuran kampung & $200.000,00$ & $200.000,00$ \\
\hline & & & & 10 & Listrik \& air & $150.000,00$ & $125.000,00$ \\
\hline & & & & 10 & Lain-lain & $200.000,00$ & $100.000,00$ \\
\hline & Jumlah & $7.000 .000,00$ & $6.500 .000,00$ & & Jumlah & $6.150 .000,00$ & $5.775 .000,00$ \\
\hline & Saldo & $850.000,00$ & $725.000,00$ & & & & \\
\hline
\end{tabular}

Para peserta pendampingan melalukan praktek dengan antusias melakukan simulasi pengelolaan keuangan berbasis akuntansi dan mereka tertarik untuk mempraktekkan dalam kehidupan sehari-hari.

\section{KESIMPULAN}

Berdasarkan pembahasan yang telah dilakukan, maka kesimpulan yang dapat diambil dari pengabdian masyarakat ini adalah sebagai berikut: (1) masyarakat membutuhkan usaha kreatif untuk meningkatkan pendapatan dan mereka tertarik untuk memulai usaha kreatif, (2) masyarakat memerlukan pengetahuan pengelolaan keuangan berbasis akuntansi keluarga dan masyarakat antusias untuk menerapkan dalam kehidupan sehari-hari. Melalui usaha kreatif untuk meningkatkan pendapatan dan pengelolaan keuangan berbasis akuntansi keluarga insya Allah dapat tercipta ketahanan ekonomi masyarakat.

\section{DAFTAR PUSTAKA}

Andes, R. J., \& Sunaryanto, L. T. (2020). Peran promosi penjualan melalui instagram terhadap penjualan sayur organik di PO. Sayur Organik Merbabu (SOM). Jurnal Sosial Ekonomi Pertanian, 16(1), 27-36. https://doi.org/10.20956/jsep.v16i1.10244

BPS. (2020). Kecamatan Pabelan dalam angka. Retrieved 15 May 2021, from Badan Pusat Statistik Kabupaten Semarang

Indika, D. R., \& Jovita, C. (2017). Media sosial instagram sebagai sarana promosi untuk meningkatkan minat beli konsumen. Jurnal Bisnis Terapan, 1(01), 25-32. https://doi.org/10.24123/jbt.v1i01.296

Laudon, K. C., \& Traver, C. G. (2014). E-commerce Essentials: Pearson.

LPPM. (2020). Buku Panduan Pengabdian Masyarakat Internal Unissula. LPPM Universitas Islam Sultan Agung. 


\section{Indonesian Journal of Community Services}

Volume 3, No. 2, November 2021

http://jurnal.unissula.ac.id/index.php/ijocs

DOI: http://dx.doi.org/10.30659/ijocs.3.2.135-144

Manurung, D. T., \& Sinton, J. (2013). Urgensi Peran Akuntansi dalam Rumah Tangga (Studi Fenomenologis pada Dosen-Dosen Akuntansi di Universitas Widyatama Bandung).

Raharjo, T., \& Prasetyo, D. H. (2018). Pendampingan Optimalisasi Media Sosial Sebagai Sarana Pemasaran Produk. Jurnal Pemberdayaan Masyarakat Madani (JPMM), 2(2), 288-306. https://doi.org/10.21009/JPMM.002.2.08

Sugiri, D. (2020). Menyelamatkan usaha mikro, kecil dan menengah dari dampak pandemi Covid19. Fokus Bisnis: Media Pengkajian Manajemen dan Akuntansi, 19(1), 76-86. https://doi.org/10.32639/fokusbisnis.v19i1.575

Suwardjono, S. Memahamkan akuntansi dengan penalaran dan pendekatan sistem. Journal of Indonesian Economy and Business, https://journal.ugm.ac.id/jieb/article/view/39435

Vernia, D. M. (2017). Optimalisasi Media Sosial Sebagai Sarana Promosi Bisnis Online Bagi Ibu Rumah Tangga Untuk Meningkatkan Perekonomian Keluarga. UTILITY: Jurnal Ilmiah Pendidikan Dan Ekonomi, 1(2), 105-118. https://doi.org/10.30599/utility.v1i2.71

Wibisono, I. K., \& Saputro, E. P. (2020). Strategi Komunikasi Pemasaran Toko Hijab Nabil Sabil Dalam Menambah Pelanggan Menggunakan Media WhatsApp. Universitas Muhammadiyah Surakarta, 